\title{
Peningkatan Keterampilan Pembelajaran Daring untuk Guru Taman Kanak-Kanak
}

\author{
Improving Daring Teaching Skill for Kindergarten Teachers \\ ${ }^{1)}$ Sulasih Nurhayati, ${ }^{2)}$ Titik Wahyuningsih, ${ }^{3)}$ Condro Nur Alim, ${ }^{4 *}$ Khristianto, \\ ${ }^{5}$ Ambar Pujiyatno, ${ }^{6}$ Fitri Rakhmawati \\ 1,2,3,4,5,6) Program Studi Sastra Inggris, Fakultas Sastra, \\ Universitas Muhammadiyah Purwokerto \\ Jl. KH. Ahmad Dahlan, Dukuhwaluh, Kembaran, Purwokerto \\ *email: khristianto@ump.ac.id
}

DOI:

10.30595/jppm.v5i1.10229

Histori Artikel:

Diajukan:

30/03/2021

Diterima:

07/05/2021

Diterbitkan:

08/07/2021

\section{ABSTRAK}

Pandemi COVID-19 menimbulkan efek negatif terhadap pembelajaran di Taman Kanak-Kanak (TK). Para guru merasa pembelajaran daring tidak efektif sekaligus melelahkan. Mereka harus menghabiskan lebih banyak waktu, tetapi hasilnya jauh dari harapan. Tujuan pelaksanaan kegiatan pengabdian ini adalah untuk mengatasi permaslahan pembelajaran pembelajaran daring di TK, dengan memberikan penyuluhan dan pelatihan metode dan media pembelajaran daring. Dari hasil pelatihan, peserta mendapatkan suntikan semangat dan harapan baru untuk melaksanakan pembelajaran daring secara lebih baik melalui penggunaan aplikasi LearningManagement System LMS, yang memadukan pembelajaran sinkronus dan non-sinkronus. Selain itu, disarankan agar para guru lebih memanfaatkan pembelajaran secara berkelompok agar pelaksanaan pembelajaran lebih kondusif bagi anak-anak, dan secara waktu lebih efisien untuk para guru. Hal lain yang ditekankan adalah pentingnya melibatkan peran orang tua dalam pembelajaran daring.

Kata kunci: Keterampilan Daring; Anak-anak; Teknologi; Sinkronus; Asinkronus

\begin{abstract}
COVID-19 has exerted negative effects on education, including kindergarten. Teachers experienced that the daring learning had been so tiring and not very effective. They have to spend more time and energy, but the outcome is far beyond their expectation. This program was designed to help them solve the problem by giving them training on methods and media for daring learning. From the training, the teachers are motivated to conduct the learning through a learning management system (LMS) that integrates synchronous and asynchronous learning. They are also advised to rely on (small) group learning rather than individual learning to be more conducive and efficient. Another point emphasized there is the importance of the parent's role in the learning process. Thus, the school should encourage more parents' engagement in it.
\end{abstract}

Keywords: Daring Learning Skill; Kids; Technology; Synchronous; Asynchronous

\section{PENDAHULUAN}

Kemunculan pandemik COVID-19 berpengaruh terhadap pelaksanaan pendidikan secara negatif. Efek ini terjadi bukan hanya di Indonesia bahkan di seluruh dunia (Yulia, 2020). Pengaruh negatif itu makin terasa dalam pendidikan untuk anak-anak pra-sekolah (Adhe et al., 2020; Hapsari et al., 2020; Yuliana, 2020). Pelaksana pendidikan harus bersusahpayah untuk bertahan dan megembangkan pembelajaan, karena keterbatasan dana dan minimnya dukungan sosial (Solekhah, 2020). Kesulitan serupa juga dialami oleh orang tua mereka (Rama (2020) dalam (Solekhah, 2020). 
Dari perspektif yang berbeda, situasi pandemik juga dapat menjadi peluang emas untuk membangun hubungan yang lebih dekat antara orang tua dan anak-anak. Seharusnya pembelajaran bagi anak-anak justru bisa cukup berhasil dengan waktu yang lebih banyak dihabiskan oleh orang tua di rumah. Tanpa peran mereka, pendidikan anak usia dini sungguh akan sulit dicapai (Adhe et al., 2020). Ibu adalah orang tua yang terlibat secara aktif dalam pembelajaran daring untuk anak-anak; peran mereka mencakup pengasuhan, komunikasi interaktif, strategi belajar di rumah, dan juga pengambilan keputusan (Hapsari et al., 2020).

Berdasarkan landasan filosofis, penyelenggaraan pendidikan anak usia dini bertujuan memberikan hak kepada anak untuk tumbuh dan berkembang sesuai dengan potensi yang dimilikinya sehingga menjadi anak bangsa yang diharapkan, yakni menjadi manusia Pancasilais atau manusia Indonesia seutuhnya (Ariyanti, 2016). Sayangnya, COVID-19 telah menyebabkan semua tatanan kehidupan yang sudah mapan menjadi berubah, termasuk di dalamnya tata kelola pendidikan dari prasekolah dasar sampai dengan perguruan tinggi. Sayangnya masyarakat Indonesia, dibandingkan mereka di banyak negara lain, dapat dikatakan tidak siap menghadapi situasi wabah ini, setidaknya tampak dari kepemilikan komputer untuk bekerja yang hanya $34 \%$, dibandingakn dengan negara-negara yang lebih siap (95\%). Dengan segala keterpaksaan, masyarakat Indonesia memang dipaksa oleh keadaan untuk menjalani pembelajaran model baru ini (Yulia, 2020).

Hal ini pula yang dialami oleh para guru TK UMP. Berbagai cara dilakukan untuk tetap melaksanakan pembelajaran daring kepada para peserta didik, diantaranya adalah: 1) melakukan pembelajaran lewat video call baik per kelompok maupun per peserta didik, 2) mengunggah video atau gambar materi pembelajaran ke media sosial dan Youtube, dan 3) memonitor perkembangan peserta didik melalui Lembar Kerja Anak LKA yang diisi oleh orangtua. Namun demikian hasil yang diperoleh dari cara pembelajaran di atas belum maksimal. Hal ini tampak dari tingkat kejenuhan para peserta didik, orangtua, dan para guru sendiri.
Hal serupa juga dinyatakan oleh satu kajian (Muhdi et al., 2020), yang menyatakan bahwa pembelajaran daring untuk pendidikan pra-sekolah memang menghasilkan pengaruh yang beragam, baik negatif atau pun positif. Muhdi et al. (2020) juga menyimpulkan dari hasil investigasinya bahwa pembelajaran daring untuk kelompok pendidikan ini masih dihadapkan setidaknya beberapa hambatan di lapangan yaitu: kemampuan guru dan orang tua, kemampuan ekonomi, kurangnya fasilitas, dan juga hambatan pedagogis.

Berdasarkan analisis situasi di atas, tujuan dari kegiatan pengabdian ini adalah 1) memberikan pemahaman mengenai pembelajaran daring, 2) memberikan pelatihan best practices pembelajaran daring untuk anakanak, dan 3) memberikan perangkat pembelajaran daring yang memadukan pembelajaran, penugasan, dan evaluasi.

\section{METODE PELAKSANAAN}

Berdasarkan rumusan permasalahan di atas, solusi yang ditawarkan adalah sebagai berikut: 1) memberikan pelatihan kepada para guru tentang berbagai metode dan media teknologi pembelajaran daring, 2) memberikan pelatihan kepada para guru tentang metode pengembangan materi pembelajaran untuk anak usia dini secara daring. Solusi ini mengacu kepada pentingnya metode pembelajaran berbasis integrated technology yang dianggap sesuai dengan kondisi terkini akibat pandemik. Penggunaan teknologi dalam proses pembelajaran di kelas pada anak-anak dapat memberikan dampak positif, di antaranya: a) memotivasi anak-anak dan membantu perkembangan kognitif dan sosial mereka,b) membantu meningkatkan konsep-diri anak dan sikap mereka terhadap proses pembelajara, dan c) meningkatkan ketrampilan berkomunikasi dan kerjasama anak (Kingsley S. dan Ismail Z., 2015: 222).

Pelaksanaan program telah dilakukan pada 9 Maret 2021 di TK UMP, Jalan KH A. Dahlan Dukuhwaluh, Kembaran, Purwokerto. Kegiatan tersebut diikuti oleh semua guru TK dan PAUD di sekolah tersebut sebanyak 15 guru, termasuk kepala sekolah. Kegiatan inti meliputi: 1) penyuluhan kepada mitra tentang kesadaran akan pentingnya pembelajaran daring 


\section{Sulasih Nurhayati, Titik Wahyuningsih, Condro Nur Alim, Khristianto, Ambar Pujiyatno, Fitri Rakhmawati}

Peningkatan Keterampilan Pembelajaran Daring untuk Guru Taman Kanak-Kanak

di saat dan setelah pandemic, 2) pelatihan kepada mitra tentang metode pembelajaran daring bagi anak usia dini, 3) pelatihan media pembelajaran daring bagi anak usia dini, dan juga 4) pelatihan metode pengembangan materi pembelajaran daring bagi anak usia dini.

\section{HASIL DAN PEMBAHASAN}

Kegiatan pengabdian ini dilaksanakan dengan memberikan penyampaian materi mengenai karakter anak-anak yang unik dan sifat pembelajaran daring yang berbeda dengan pembelajaran konvensional. Sebelumnya pengertian mengenai situasi pandemi dan tantangannya ditanamkan juga kepada para guru TK, di mana semua orang di mana pun menghadapinya baik di Indonesia atau pun di mana pun. Pun efeknya juga menimpa semua bidang kehidupan. Sikap "menerima" dan menjalankan kegiatan kehidupan secara bertanggung jawab adalah hal penting agar para guru tidak berputus asa oleh kesulitan pengajaran di masa pandemi, terlepas dari hasil yang mungkin tidak maksimal, tidak sesuai dengan harapan. Kadang hasil belajar siswa juga tidak sebanding dengan upaya atau energi yang dikeluarkan untuk mewujudkannya.

Berdasarkan hasil diskusi kelompok diketahui bahwa selama ini para guru TK hanya mengandalkan media sosial Whatsapps (WA) dan video pembelajaran sebagai wahana pembelajaran bagi anak-anak. Video pembelajaran ini juga dikirimkan melalui WA sebelum pembelajaran langsung (sinkronus) melalui panggilan video (video call) melalui WA. Para guru melakukan kegiatan ini secara individual untuk tiap siswa. Masing-masing siswa diberikan jatah waktu untuk "belajar" bersama guru setiap hari secara daring dengan panggilan langsung tersebut. Sayangnya, tidak semua siswa mau belajar dengan gurunya melalui panggilan ini.

Namun demikian, apa yang guru lakukan tidak selalu selaras dengan dukungan orang tua yang secara langsung mendampingi anak-atau dapat digantikan menggantikan guru sebagai role model sekaligus fasilitator agar anak-anak mau tetap belajar, bahkan dengan waktu yang sangat fleksibel-di luar jadwal pelajaran. Minimnya peran orang tua dalam mendukung belajar anak-anak tampak dari jumlah feedback atau hasil pengumpulan tugas yang kurang lebih hanya 30\% dari keseluruhan siswa di kelas. Artinya, sebagian besar anak (70\%) tidak didampingi secara baik oleh orang tua mereka, sehingga mereka lalai untuk mengumpulkan tugas sekolah. Salah satu alasan yang disebutkan oleh guru adalah bahwa orang tua lebih berfokus mendampingi anakanak mereka yang sudah berada di tingkat pendidikan yang lebih tinggi. Orang tua menganggap bahwa tugas-tugas TK tidaklah sepenting tugas-tugas anak mereka yang sudah di Sekolah Dasar atau Menengah. Fakta serupa juga diungkapkan oleh seorang pelaku dan pemerhati pendidikan anak usia dini (Yuliana, 2020), sehingga ia sendiri sampai mempertanyakan apakah pendidikan usia dini masih perlu.

Sebagai TK yang berbasis Islam, para guru sangat khawatir dengan kegagalan penanaman kebiasaan-kebiasaan (habit) harian seperti sholat dan hafalan baik doa maupun surat. Mereka menemukan kesulitan dalam mencapai tugas-tugas tersebut, padahal kebiasaan-kebiasaan tersebut merupakan halhal pokok untuk membangun landasan karakter yang baik. Waktu yang terbatas, dan pembelajaran yang berjarak dirasakan mereka jauh dari memadai untuk mewujudkan tujuan ini. Dalam hal ini, mereka hanya dapat mengandalkan peran orang tua yang lebih besar, karena merekalah yang langsung berhadapan dengan anak-anak dengan waktu yang jauh lebih leluasa dan dapat menyesuaikan mood belajar anak-anak. Sayangnya tidak semua orang tua (bila tidak mau disebut "hanya sedikit") yang bersikap kooperatif dalam pendidikan di situasi yang memang tidak lazim ini. Hal ini senada dengan apa yang disimpulkan satu kajian bahwa peran orang tua dalam pembelajaran daring semakin besar, bahkan melebihi peran gurunya. Orang tua berkewajiban untuk mengawasi pembelajaran, turut melaksanakan pembelajaran, dan membantu guru dalam pelaksanaan penilaian (Solekhah, 2020:1).

Sebagai tindak lanjut yang akan dilaksanakan dengan pendampingan tim pelaksana adalah pengembangan LMS, learning management system, yang khas anak-anak. Keberadaan LMS diharapkan dapat memudahkan para guru dalam mempersiapkan 
pembelajaran. Mereka dapat mengunggah video pembelajaran, memberikan opsi game pembelajaran, mengirimkan tugas-tugas bagi orang tua dan anak-anak, serta memantau kegiatan para siswa di rumah masing-masing. Selain itu, fungsi dokumentasi tugas yang lebih tertatat juga akan mungkin dilakukan dengan adanya LMS tersebut.

Dalam pelaksanaan pembelajaran, LMS ini akan memungkinkan dua mode pembelajaan daring yakni yang sinkronus (atau langsung atau live) dan yang non-sinkronus (tidak langsung). Selain itu, LMS ini juga dapat dikombinasikan dengan penggunaan media pembelajan lain yang sifatnya sinkronus, seperti video call WA atau pun Google Meet. Dengan cara ini, para guru tidak harus selalu melakukan panggilan secara individu, melainkan dapat dilakukan secara massal seluruh kelas, atau pun dibuat dalam kelompok-kelompok yang lebih kecil. Daring kelompok akan menciptakan suasana yang lebih mendekati kelas konvensional, sehingga anak-anak akan lebih terhibur dan atmosfernya lebih ramah karena mereka tidak sendiri harus berhadapan dengan gurunya.

Hal lain yang ditekankan oleh tim adalah penugasan yang tidak monoton, dan murni pembelajaran. Tugas-tugas yang sifatnya kognitif akan lebih baik apabila diintegrasikan dengan kegiatan sosial keseharian yang bisa dilakukan oleh anak-anak bersama orang tua mereka. Tugas semacam ini justru dilakukan oleh ibu, ayah, atau anggota keluarga lain yang lebih dewasa. Misalnya, tugas latihan berhitung dapat dilakukan dengan mengajak anak untuk membantu menjemur pakaian mereka sendiri. Saat mereka melakukan penjemuran, mereka diajak untuk menghitung satu-satu persatu pakaian yang mereka jemur itu. Tugas membaca pun dapat dilakukan secara sambi lalu dengan mengajak anak-anak untuk bersepeda, dan berhenti beristirahat ketika ada tulisan di pinggir jalan. Mereka akan mengeja huruf-huruf yang ada, dan orang tua dapat mempersiapkan hadiah-hadiah kecil untuk memotivasi mereka. Atau kegiatan keseharian apa pun yang memungkinkan anak untuk bealajar sebagai bagian dari aktivitas sosial. Dengan demikian, keterlibatan orang tua dalam pembelajaran akan tidak menjadi beban tersendiri, melainkan menjadi bagian dari rutinitas keseharian.

\section{Respon dan Evaluasi Peserta}

Secara umum, respon peserta pelatihan cukup baik dan antusias. Selama pelatihan semua peserta memperhatikan pemaparan materi dan memberikan respon pada apa yang disampaikan oleh pemateri. Tidak ada satu pun peserta yang keluar dari pelatihan hingga akhir program. Antusiasme mereka terlihat pada sesi diskusi; beberapa orang menyampaikan pertanyaan yang terkait materi, yang lainnya berkeluh kesah tentang beratnya mengajar di masa pandemi. Di antara mereka, bahkan ada yang bertanya berulang-ulang mengenai berbagai masalah pembelajaran daring. Dapat disimpulkan bahwa tema pelatihan memang sesuatu yang mereka butuhkan dan harus mereka hadapi setiap hari sebagai pengajar.

Selain evaluasi kualitatif berdasarkan hasil observasi selama pelaksanaan, penilaian pelaksanaan program juga dilakukan melalui kuesioner daring yang diberikan kepada peserta. Kuesioner ini dibagikan langsung setelah pelatihan selesai. Seluruh peserta mengisi kuesioner pada satu hari paska pelatihan. Pelaksanaan evaluasi reseptif yang cepat diharapkan betul-betul merefleksikan persepsi mereka terhadap tahapan-tahapan kegiatan yang dilaksanakan. Hasil dari kuesioner tersebut disajikan sebagai berikut.

\section{Penilaian Materi}

Terhadap aspek materi yang disajikan, para peserta menyampaikan kesan yang baik. Sebagian besar menyatakan "setuju" bahwa materi-materi tersebut informatif, mudah dipahami, sesuai kebutuhan dan mendukung kinerja. Kuesioner ini menggunakan skala Likert dengan 5 opsi, tetapi tidak ada peserta yang memilih 1 atau 2. Dari tiga pilihan yang muncul, yang paling banyak muncul adalah pilihan 4, yang berarti "setuju"-yang bila dirata-rata dari keempat aspek materi tersebut, masing-masing mendapatkan persetujuan $41 \%$. Sementara untuk pilihan "sangat setuju" tidak cukup banyak. Tetapi bila dibandingkan dengan pilihan 3 (cukup), angkanya masih lebih tinggi di atasnya. Gambaran ini lebih tampak jelas dari Tabel 1. 
Sulasih Nurhayati, Titik Wahyuningsih, Condro Nur Alim, Khristianto, Ambar Pujiyatno, Fitri Rakhmawati

Peningkatan Keterampilan Pembelajaran Daring untuk Guru Taman Kanak-Kanak

Tabel 1. Persepsi peserta terhadap kualitas materi

\begin{tabular}{lcccc}
\hline & $\begin{array}{c}\text { Informatif } \\
(\%)\end{array}$ & $\begin{array}{c}\text { mudah dipahami } \\
(\%)\end{array}$ & $\begin{array}{c}\text { sesuai kebutuhan } \\
(\%)\end{array}$ & $\begin{array}{c}\text { mendukung kinerja } \\
(\%)\end{array}$ \\
\hline cukup & 12,5 & 37,5 & 25,0 & 37,5 \\
setuju & 50,0 & 37,5 & 37,5 & 37,5 \\
sangat setuju & 37,5 & 25,0 & 37,5 & 25,0 \\
\hline Total & 100 & 100 & 100 & 100 \\
\hline
\end{tabular}

\section{Kepuasan terhadap program}

Trend serupa juga tampak dari hasil penilaian kepuasan peserta terhadap pelaksanaan program. Setengah dari peserta menyatakan "puas" terhadap kegiatan yang dilakukan. Sisanya terbagi secara sama antara yang berpendapat cukup dan sangat puas. Dengan kata lain, secara umum kegiatan ini memberikan kesan yang positif terhadap peserta. Kecenderungan yang positif ini juga terlihat dari penilaian mereka terhadap relevansi tiap sesi acara, pilihan mereka terbagi dua menjadi "relevan" dan "sangat relevan".

Tabel 2. Kepuasaan peserta terhadap program

\begin{tabular}{lcc}
\hline & Kepuasan $(\%)$ & Relevansi tiap sesi (\%) \\
\hline Cukup & 25 & 0 \\
Puas/relevan & 50 & 50 \\
Sangat puas/relevan & 25 & 50 \\
\hline Total & 100 & 100 \\
\hline
\end{tabular}

Kesan yang positif (Tabel 2) juga terekam dari isian mereka pada pertanyaan singkat mengenai manfaat dan harapan mereka terhadap program yang telah dilaksanakan. Mereka secara umum menyatakan bahwa kegiatan tersebut bermanfaat dalam menambah "pengetahuan, wawasan, ilmu" pembelajaran daring yang menarik agar anak-anak didik mereka lebih tertarik dan antusias. Mereka meyakini bahwa aplikasi bersama LMS, akan "lebih memudahkan dan meringkan dalam pemberian tugas dan lain-lain".

Kesan yang baik tersebut juga tampak dari respon mereka terhadap pertanyaan yang netral, "Ada komentar lain terkait sesi atau agenda acara secara keseluruhan?" Jawaban mereka tegas sekali menyuratkan kesan dan harapan yang positif. Sebagian ada yang mengulang bahwa kegiatan tersebut baik dan bermanfaat, dan mereka berterima kasih atas adanya program. Cukup banyak peserta yang menyamapaikan harapan akan adanya tindak lanjut. Sebagian lain mengungkapkan bahwa mereka senang mengikuti kegiatan, sehingga "waktu tidak terasa habis".

Dari persepsi evaluasi yang positif tersebut, ada harapan dari tim pelaksana bahwa para guru akan kembali semangat dan termotivasi untuk memberikan pembelajaran jarak jauh di masa pandemi ini dengan lebih baik. Tujuan akhirnya adalah mereka dapat menghadirkan pembelajaran yang menghibur, menyenangkan dan penuh makna bagi pengembangan karakter dari calon generasi bangsa. Untuk memenuhi harapan peserta pelatihan, tim merencanakan program pengabdian lanjutan - terutama yang lebih diarahkan pada pelibatan orang tua dalam pendampingan pembelajaran anak di masa pandemi.

\section{SIMPULAN}

Program yang dilaksanakan untuk membantu para guru TK UMP untuk mengatasi permasalahan pembelajaran daring di masa pandemi telah terbukti memberikan semangat dan motivasi mereka untuk selalu memberikan 
Sulasih Nurhayati, Titik Wahyuningsih, Condro Nur Alim, Khristianto, Ambar Pujiyatno, Fitri Rakhmawati

Peningkatan Keterampilan Pembelajaran Daring untuk Guru Taman Kanak-Kanak

pembelajaran yang terbaik. Pendampingan yang akan dilakukan untuk menyediakan LMS diyakini akan mampu meringkan tugas mereka dengan mengkombinasikan pembelajaran yang sinkronus dan non-sinkronus. Pembelajaran berkelompok akan lebih menggairahkan pembelajaran para siswa, dibandingkan dengan pembelajaran individu yang selama ini biasa dilakukan, yang juga kurang efisien secara waktu. Respon dan evaluasi positif dari para

\section{DAFTAR PUSTAKA}

Adhe, K. R., Maulidiya, R., Al Ardha, M. A., Saroinsong, W. P., \& Widayati, S. (2020). Learning During the Covid-19 Pandemic: Correlation Between Income Levels And Parental Roles. Jurnal Obsesi: Jurnal Pendidikan Anak Usia Dini, 5(1), 293. https://doi.org/10.31004/obsesi.v5i1.554

Ariyanti, Tatik. 2016. "Pentingnya Pendidikan Anak Usia Dini Bagi Tumbuh Kembang Anak (The Importance of Childhood Education for Child Development)". Jurnal Dinamika Pendidikan Dasar Volume 8, No 1, Maret 2016: 50 - 58.

Hapsari, S. M., Sugito, S., \& Fauziah, P. Y. (2020). Parent's Involvement in Early Childhood Education during the Covid-19 Pandemic Period. Jurnal Pendidikan Progresif, 10(2), 298-311. https://doi.org/10.23960/jpp.v10.i2.20201 4

Kingsley S., Olisah and Ismail Z., Mohamed. 2015. "Web Based E-Learning System for Pre-School Kids". International Journal peserta semoga menjadi indikasi bahwa pelatihan yang dilakukan akan terserap dan merembes dalam pembelajaran daring untuk anak-anak pra-sekolah yang mereka bimbing. Upaya lanjutan yang perlu dilakukan adalah kegiatan yang pengabdian yang juga melibatkan orang tua siswa untuk meningkatkan kesadaran mereka akan pentingnya peran orang tua dalam pembelajaran daring.

of Information System and Engineering. Vol. 3 (No.1), April, 2015. pp 219-232.

Muhdi, Nurkolis, \& Yuliejantiningsih, Y. (2020). The Implementation of Daring Learning in Early Childhood Education During the Covid-19 Pandemic. JPUD Jurnal Pendidikan Usia Dini, 14(2), 247261.

https://doi.org/10.21009/JPUD.142.04

Solekhah, H. (2020). Distance Learning of Indonesian Early Childhood Education (PAUD) during the Covid-19 Pandemic. International Journal of Emerging Issues in Early Childhood Education, 2(2), 105115. https://doi.org/10.31098/ijeiece.v2i2.409

Yulia, H. (2020). Daring Learning to Prevent the Spread of Pandemic Corona Virus in Indonesia. ETERNAL (English Teaching Journal), 11(1). https://doi.org/10.26877/eternal.v11i1.606 8

Yuliana, M. (2020, October). Does early childhood education still matter during COVID-19? Jakarta Post, 6. 